\title{
A Study of Tea Pluckers' Perception on the Introduction of Tea Plucking Machines in James Finlay's Kenya
}

\author{
Beatrice Chepwogen Soi \\ Bomet University College (A Constituent College of Moi University, Eldoret), P O Box 701 - 20400 \\ BOMET, KENYA.
}

\begin{abstract}
This study sought to assess the perception of tea pluckers on the introduction of tea plucking machines in James Finlay's Kenya. The research was a case study of one of the major tea industry players; James Finlay's Kenya Ltd. The target populations were all the tea estates in James Finlay's (K) Ltd in Kericho County. James Finlay's has a total of 13 Tea estates. There are a total of 10,262 tea pluckers in the company. A sample of five estates was considered and a sample of $20 \%$ of tea pluckers in these estates was taken for the study. A representative group according to Mugenda and Mugenda is one that is at least $10 \%$ of the population of interest. The above sample was therefore representative. Data was collected using structured questionnaires and interview methods. The data collected was supplemented with available literature review on the subject of study. The response from crossfunctional sample group was analysed using descriptive statistical techniques in form of frequency distribution tables, percentages, pie charts, and computer packages. The study found that the tea pluckers viewed the introduction of the machines negatively; they interpreted it as a way of rendering them obsolete and eventually retrenching them. They therefore did not fully support its implementation
\end{abstract}

Key words - Perception, Tea plucking machines, tea industry, implementation, obsolete.

\subsection{Background Of The Study}

The introduction of Tea plucking machines in Tea plantations in Kenya by James Finlay's Ltd has elicited a lot of resistance from the workforce and trade unionists. Companies that have successfully replaced live labour have had to dispel the notion of machine subordination by employees. Where psycho and socio economic preparations for the stock and stake holders are not done satisfactorily by the change agents, the results and benefits of technical substitution have been disproportionate. In order to achieve a smooth transition a very elaborate change management strategy is required. It is worth noting that where technology is going to alter the work scene both on new and better ways of doing things and terminating services of staff, the success of such depend on the extent of change management.

In the agricultural sector and tea production in particular, there has been stagnating or declining demand in most of the main traditional markets, and a general decline in tea prices in the world market. This decline in demand and prices has negative implications on continuous and consistent deployment of the human resource. Tea production has been associated with a number of problems one being high cost of production; labour being the major contributing cost element. It is estimated that it costs growers $\$ 1.2$ to produce a kilogram of tea with labour and welfare constituting 60 percent of production costs. It was observed by tea exporters that Kenya must mechanize tea picking for the industry to survive spiraling production costs and diversify into products such as green tea that are attracting more demand worldwide. The tea plantations in the study are owned by multinational companies which engage in tea plantation farming, as defined in the ILO Plantations Conventions, No.110 (1958). The companies in agricultural undertaking regularly employ 
workers for cultivation and production of tea for commercial purposes.

\subsection{Statement of The Problem}

Tea pluckers in James Finlay's Kenya limited Kenya, downed their tools protesting over the use of tea plucking machines on the introduction of tea plucking machines, tea pluckers in tea James Finlay's went on strike citing the employer's determination to replace them with machines tea pluckers and pruners the Kenya plantation and agricultural workers union (KPAWU) called for a nationwide boycott of tea plucking over the introduction of mechanized tea picking. These protests affected production since tea pluckers were not involved in the change process.

Given that in any business environment change is a constant factor and given that technology will always feature in these changes, it is important to study the effects of the above individual resistant forces to the introduction of tea plucking machines at James Finlay's Kenya limited. And further recommend a change strategy to mitigate resistance to technological change in the tea industry that will form the basis for implementation of such change

\subsection{Objective of The Study}

To find out how the tea pluckers perception affected the introduction of tea plucking machines in James Finlay's Kenya

\subsection{Research Question}

Did the tea pluckers perception on the reasons to introduce tea plucking machines affect the introduction of tea plucking machines in James Finlay's Kenya?

\subsection{Significance Of The Study}

This study is of key significance to organizations that are re-engineering their business processes by way of technological change since it sets out the importance of cross-functional approach to the processes of instituting change in an organization in order to avert industrial disputes and effectively implement change.

\subsection{The Scope of The Study}

The scope of this study was the major tea industry player, James Finlay's (K) Ltd based in Kericho County, Kenya. James Finlay's (K) Limited has been selected for case study since it is one of the Tea industry players whose workforce was involved in an industrial dispute over the introduction of Tea plucking machines.

\subsection{The Limitations of The Study.}

The study was limited to the impacts of technology on tea pluckers' productivity, resistance to technology from tea pluckers but excludes the benefits of the technology.

\subsection{Literature Review}

\subsection{Introduction}

The business world is dynamic, and managers face complex and challenging bottlenecks and opportunities. They must ensure that scarce resources are used effectively, and at the same time, find ways of sustaining the long-term effectiveness and survival of the organizations for which they work; organizations must change with the times. As suggested by Collin(1998), effectiveness must include the ability to proactively recognize the right things to do in the future for instance, the right products and services to offer, the appropriate technologies to exploit, the best procedures and structures to introduce, to find, recruit and retain people with appropriate skills. Effectiveness entails the capacity to adapt to changing circumstances hence the need for change. To address these changing circumstances technology comes in handy and it is the prerogative of a particular company to identify the most appropriate and sustainable technological inventions. 
Companies realize that change for the better is a desirable phenomenon. It behooves the company strategists to decipher through the change options and identify the most viable and choose which technology if any is appropriate. According to Kanter (1992), change can be regarded as the process of analyzing "the past to elicit the present actions required for the future". It encompasses moving from a present state, through a transition state to a future desired state. The common saying is that change is now an everyday part of our lives. Much as technology is supportive of the desired change, if adequate preparations are not made for change its intended benefits may be lost and the associated impacts may be negative. Change must therefore be managed like any other projects or tasks in an organisation.

\subsection{Technology and change Management.}

According to Holger (2005) change management is the process, tools and techniques to manage the peopleside of change processes, to achieve the required outcomes, and to realize the change effectively within the individual change agent, the inner team, and the wider system. Change management can take many forms and include many change environments while the kind of technology being adopted determines the extent of change. This research study will restrict itself to organizational change management in the advent of capital intensive technological deployment. Organizational change management is the process of developing a planned approach to change in an organization. Typically the objective is to maximize the collective benefits for all people involved in the change and minimize the risk of failure of implementing the change. According to Hogler (2005), to be effective, change management should be multi-disciplinary, touching all aspects of the organization. However, at its core, implementing new procedures, technologies, and overcoming resistance to change are fundamentally human resource management issues.

\subsection{The psychology of change}

Warren et al (1999) observed that attitudes towards change result from a complex interplay of emotions and [cognitive] processes. Because of this complexity everyone reacts to change differently. The perceptive process and subsequent valuation of individual impact of technological application to his/her job will determine the viability of change on the individual. On the positive side, change is seen as akin to opportunity, rejuvenation, progress, innovation, and growth. Similarly, change can also be seen as akin to instability, upheaval, unpredictability, threat, and disorientation. Whether employees perceive change with fear, anxiety and demoralization, or with excitement and confidence, or somewhere in between, depend partially on the individual's psychological makeup, partially on management's actions, and partially on the specific nature of the change. Because an organization has diverse talents and employees' ambitions, a technology that is going to favour the prepared individuals will face less resistance while those who feel that the new technology will render them irrelevant will be resistant to introduction of the new technologies. It is the responsibility of the management to initiate change preparations across the board.

\subsection{Theoretical framework}

The study was based on Kurt Lewin's change theory (1940). Psychologist Kurt lewin formulated the classic explanation of how to implement a change in the face of resistance. To lewin, all behavior in organizations is a product of two kinds of forces-those striving to maintain the status quo and those pushing for change. Implementing change thus meant either weakening the status quo forces or building up the forces for change. Lewin's process consists of these three steps

a) Unfreezing. Unfreezing means reducing the forces that are striving to maintain the status quo, usually by presenting a provocative problem or event to get people to recognize the need for change and to search for new solutions

b) Moving. Moving means developing new behaviours, values, and attitudes, sometimes through structural changes and sometimes through the sort of HR based organizational change and development techniques in order to alter people's behavior 
c) Refreezing. Lewin assumed that organizations tend to revert to their former ways of doing things unless changes are reinforced by refreezing the organization into its new equilibrium. Lewin advocated instituting new systems and procedures (such as compensation plans and appraisal processes) to support and maintain the changes.

\subsection{Research Methodology}

\subsection{Introduction}

This chapter describes the procedures that were used in the study to collect and analyse the data.

\subsection{RESEARCH DESIGN}

This study adopted a descriptive research design. It involved field visits and surveys to collect data on the effects of individual resistant forces to introduction of tea plucking machines in James Finlay's Kenya. Mugenda and Mugenda (2010) define descriptive research as a process of collecting data in order to test hypothesis or to answer questions concerning the current status of the subjects in the.

\subsection{Target Population}

The population constituted all the tea pluckers in James Finlay's estates in Kericho County estimated at 10200. The population was made up of workers based at the following tea estates:

Kapkoros,tiluet,chepkoiben,chemasingi,chemamul,Tenduet,kaproret,bondet,kapsongoi, Chemase, Marinyin, Simotwet and Chebitet. The above estates have been selected for the study since they were the estates in which the tea pluckers strongly resisted the introduction of tea plucking machines.

\subsection{Sample Design}

The sampling design for the study was purposive; this is a deliberate non-random method of sampling which aimed to select a sample of tea estates. The estates were selected because it's in these tea estates where tea plucking machines were first introduced and were strongly opposed by the tea pluckers. The researcher used purposive sampling since this method according to Mugenda and Mugenda (2010) allows the researcher to use cases with respect to the objectives of his/ her study.

\subsection{Sample Size}

A total of 312 respondents were selected randomly in the five tea estates, using the formula $(\mathrm{p} / \mathrm{n} * \mathrm{~s})$ sample size will be obtained from the sampling frame.

\section{Table 3.1 Sample size}

\begin{tabular}{|l|l|l|l|l|}
\hline NO & ESTATE & $\begin{array}{l}\text { TOTAL } \\
\text { POPULATION }\end{array}$ & $\begin{array}{l}\text { POP FREQUENCY } \\
\text { OF TEA PLUCKERS }\end{array}$ & PERCENTAGE \\
\hline 1 & Kapkoros & 632 & 63 & 20.2 \\
\hline 2 & Chemase & 404 & 40 & 12.8 \\
\hline 3 & Marinyin & 719 & 72 & 23.1 \\
\hline 4 & Simotwet & 693 & 69 & 22.1 \\
\hline 5 & Chebitet & 675 & 68 & 21.8 \\
\hline & Total & $\mathbf{3 1 2 3}$ & $\mathbf{3 1 2}$ & $\mathbf{1 0 0 . 0}$ \\
\hline
\end{tabular}

Source: JFK LTD 2010 


\subsection{Data Collection Instruments And Procedure}

Primary data was collected using the questionnaire. A set of questions, both open-ended and closed were developed for every variable. According to Robson, (2009) questionnaire method is good for descriptive research design; because it works best with standardized questions that are confident will be interpreted the same way by all respondents. The close ended questions were accompanied by a list of all possible alternatives from which the respondents were to select the answers that best described their situation, while the open ended allowed them freedom of response.

\subsection{Data Analysis}

Data obtained was analyzed using descriptive statistics. This enabled the researcher to meaningfully describe a distribution of scores or measurements using a few indices or statistics. These included frequency distribution tables, percentages, pie charts, bar charts, and related diagrams. Computer packages was also be used especially the statistical packages for social scientists (SPSS) and excel software to help draw conclusions and make recommendations from the research findings.

\subsection{Research Results}

Tea pluckers did not trust the management's motive on the introduction of tea plucking machines. Most of them viewed the introduction of the machines negatively; they interpreted it as a way of rendering them obsolete and eventually retrenching them. They therefore did not fully support its implementation.

It is also notable that most tea pluckers did not see the need of the introduction of the tea plucking machines $15 \%$ of the respondents indicated that the introduction of the machines was necessary, whereas $82 \%$ said it was not necessary. Most of them thought that hand picking tea were adequate enough. Those who saw the need understood the importance of technology and the market trends.

A good percentage (83\%) feared that the tea plucking machines would eventually replace them. Only $16 \%$ were confident that the machines would not completely replace them.

The high percentage above denotes that this fear is indicative of negative perception towards the introduction and use of TPM. It also implies that the workers who were uncertain of the effects of the tea plucking machines staged a strong resistance.

\subsection{Conclusion}

Based on the research findings, it's evident that tea pluckers perception on the reasons for the introduction of the tea plucking machines greatly contributed to the strong resistance to the tea plucking machines. The pluckers did not trust the management's motive. They viewed it as a way in which the company would want to cut on cost of production by having the few machines replace the many illiterate tea pluckers in various tea estates. They perceived it as a way of rendering them obsolete and therefore a good reason to retrench them

Most pluckers feared the losses they would incur if they lost their jobs, since this was the only source of income for most of them who did not have any form of training that would enable the secure employment elsewhere. Most of the pluckers have lived in the estates all their lives and retrenching them will mean they will be forced to leave the estates quarters and relocate yet most of them did not have a place to relocate to. Fear of losing their jobs was therefore one of the major factors that led to the strong resistance to the introduction of tea plucking machines.

\subsection{Recommendations}

Based on the outcomes of the study, the following recommendations can be made: The company's 
management should clearly explain to the tea pluckers the motives and reasons for the sudden introduction of the tea plucking machines. This should be clearly articulated so as to avoid speculation, undue conclusions, and rumour mongering amongst the tea pluckers.

Workers should be psychologically prepared before a new technology is introduced. By so doing, resistance to technology could possibly be averted.

\section{References}

[1] Collins, A. Carwall 2009 Managing Change in Organizations. New York Prentice Hall, International.

[2] Mugenda, O Mugenda A (2010).Research methods, Quantitative and qualitative approaches, Nairobi, Acts Press

[3] Kenya Tea Gowers association (KTGA) and Kenya plantation and agricultural Workers union CBA (2004-2005). “Collective bargaining agreement" Nairobi, Kenya.

[4] Reuters Nov. 2006. "Tea industry pushing for Global Quality Benchmark”. Reuters

[5] Kenya Broadcasting Corporation, May 2006. "Atwoli calls for strike". Nairobi, KBC

[6] Kenya Times Nov. 2006:"Row over tea plucking machines puts Labour minister under trouble". Nairobi.

[7] Kanter RM, Stein B and Jick T (1992) the Challenge of Organizational Change

[8] . New York: The Free Press.

[9] Collins D (1998) Organizational Change: Sociological Perspectives. Routledge: London.

[10] Robbins S, Judge T, Odendaal A and Roodt G (2009) Organizational Behavior: Global and Southern African Perspectives, 2nd edn. Capetown: Pearson. 